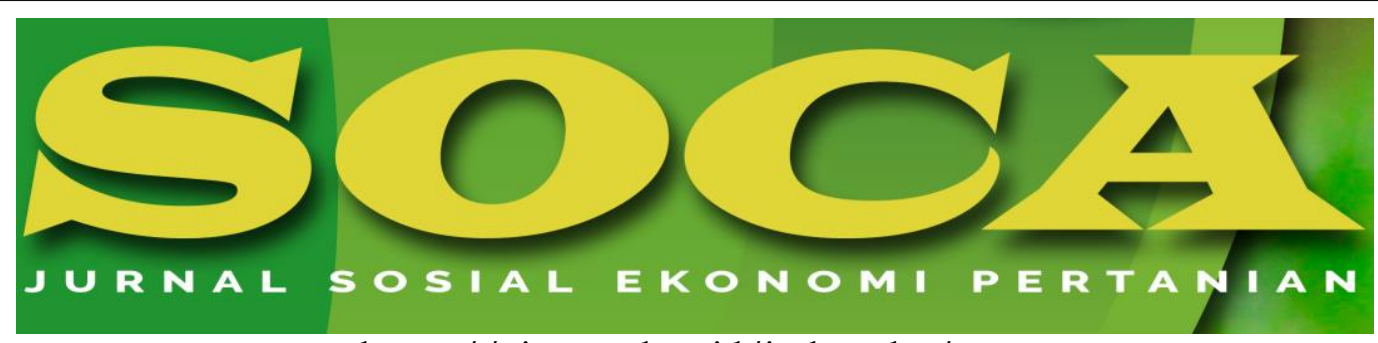

https://ojs.unud.ac.id/index.php/soca

\title{
Pepper Auction Market Development Strategy in Sleman Regency
}

\author{
Siti Afni Anisah, Agus Dwi Nugroho and Lestari Rahayu Waluyati \\ Agricultural Faculty, Gadjah Mada University \\ Flora Street, Bulaksumur Yogyakarta 55281 \\ Correspodency Email: agus.dwi.n@mail.ugm.ac.id
}

(0274) 516656

Submitted: 28 March 2020; Revised: 8 April 2020; Accepted: 27 April 2020

\section{Keywords: auction market; pepper; SWOT}

\begin{abstract}
Abstrak
The pepper auction market in Sleman Regency was formed in 2017. This market is becoming the main marketing line for all pepper traders in Sleman Regency because it is serving appropriate prices for the farmer. Some problems also appeared during the implementation of the pepper auction market. This study aimed to arrange an effective strategy in developing a pepper auction market in Sleman Regency. This study conducted from January to February 2020 involving 23 major traders who chosen by the census method and 6 stakeholders who chosen by purposive sampling technique. SWOT analysis was applied to arrange an effective strategy in developing the pepper auction market. The result showed that the most effective strategy used in developing the pepper auction market was the SO-Strategy, such as: improving product quantity and quality, improving the quality of services and creating good relationships with the assembly point management party and auction participants, and building an online product and price database system. The auction market management parties and some stakeholders are required to regularly monitor and assure the market system in conducting a market auction process appropriately. We also suggested to use modern technology devices to assure the auction transparency.
\end{abstract}

How to Cite (APA 6th Style):

Anisah, S. A., Nugroho, A. D., \& Waluyati, L. R. (2020). Pepper Auction Market Development Strategy in Sleman Regency. SOCA: Jurnal Sosial Ekonomi Pertanian, 14(2), 325-338.

https:// doi.org/https:// doi.org/ 10.24843/SOCA.2020.v14.i02.p12 


\section{INTRODUCTION}

Pepper agribusiness was vulnerable to various risk factors, such as climate conditions, pests, diseases, and improper agricultural techniques (Parining \& Dewi, 2018). But the pepper agribusiness condition in Daerah Istimewa Yogyakarta (DIY) was relatively different. DIY Province was able to develop a success and competitive pepper agribusiness using an auction market (Nugroho et al., 2018). Auction market was a trader institution employing an open and transparent system, protecting values held by the community, and improving the trade efficiency (Damona et al., 2013).

Before using the auction market, the farmer was using a long marketing line to sell their pepper commodity. The weakness of this system was the low pepper price gained by the farmer because they did not have enough power in setting proper prices for their commodity. This system affected the amount of the profit they obtained, a high cultivation and production cost made the farmer couldn' $t$ get the appropriate amount of profit (Argade \& Laha, 2018).

The pepper auction market is reliable in setting a proper pepper commodity price in DIY Province (Nugroho et al., 2018). This type of market is also able to improve community resilience in many aspects: education, health, lifestyle, information, etc (Kusumaningrum et al., 2015; Perdana, 2016). Auction market facilitating the pepper marketing process collectively. Therefore, this system also could increase the effectiveness and efficiency of the conventional marketing system used in DIY (Rusdiyana, 2015). According to the social aspect, the auction market is effective in improving farmers' collaboration which finally could developing their farmer institutional group (Raya, 2014; Fauziah, 2017).

DIY Province was formed some auction market, one of them located in Sleman Regency. This auction market formed in 2018 which was build according to the inappropriate pepper price set by the market. The pepper farmer had limited skills in negotiating with the trader. Today, the auction market plays a major role in promoting the pepper commodity. The auction marker able to set an appropriate price for the pepper commodity. The highest price offered by the trader would win the auction session. The farmer expects the auction market could sustainably conduct to help them in setting their pepper commodity's price.

As a new auction market in Sleman Regency, some problems usually happened due to the highly competitive culture between the traders. An auction market in Kulon Progo that operated in a longer duration also faces some problems. One of them is the difficulty in obtaining the agricultural commodity because of the high competitiveness between the traders and the limited space of the warehouses provided in the market (Purwandani et al., 2016). Another problem identified by Devi et al., 2015 was the trader did not pay on time to the farmer. The same problems could occur in the Sleman auction market. Some traders in Sleman also still trying to buy the pepper from the farmer (did not use the auction market). They usually did it to get a cheaper price from the farmer. This action was interrupted the auction marketing system.

Therefore, an effort to arrange a strategy in developing the auction market both on the internal and external conditions is required to carry. A comprehensive study 
to understand the effort also rarely done. Thus, this study aimed to arrange an effective strategy in developing a pepper auction market in Sleman Regency.

\section{RESEARCH METHODS}

The study location was chosen based on the purposive sampling technique. This study was conducted in Sleman Auction Market in Purwobinangun Village, Pakem District from January to February 2020. This auction market is the only auction market build in Sleman Regency in 2017.

This study employing a primary data from the interview and observation. Twenty-three major traders in Sleman Auction Market chosen by simple random sampling participated in this study. While the stakeholders were chosen by the purposive sampling technique. The stakeholder who were participated in this study were two auction market management parties, two officials from the Sleman Agricultural Department, and two farmers who sold their pepper commodity to Sleman Auction Market.

SWOT analysis used to arrange the pepper auction market strategy, build the organization, and competitive strategy effectively. An organization existed in two environments, one environment inside the organization itself and another environment outside the organization. Consequently, a comprehensive analysis must be conducted to arrange the strategic management (Gurel and Tat, 2017)

The function of the SWOT analysis is to identify the information from the environmental analysis. The environment could be classified into two sides, they are internal and external environment. The internal environment or Internal Strategic Factors Analysis Summary (IFAS) consisted of strengths and weaknesses. While the external environment or External Strategic Factors Analysis Summary (EFAS) consisted of opportunities and threats (Ommani, 2011). Those factors are shown in Table 1 and Table 2 .

Table 1. IFAS Matrix for Pepper Auction Market in Sleman Regency

\begin{tabular}{lcccc}
\hline $\begin{array}{c}\text { Internal Strategy } \\
\text { Factor }\end{array}$ & Weight & Rating & $\begin{array}{c}\text { Weight X } \\
\text { Rating }\end{array}$ & Note \\
\hline Strength & $\mathbf{X}$ & $\mathbf{X}$ & $\mathbf{X}$ \\
Total & $\mathbf{X}$ & $\mathbf{X}$ & $\mathbf{X}$ \\
Weakness & $\mathbf{X}$ & $\mathbf{X}$ & $\mathbf{X}$ \\
Total & $\mathbf{X}$ & $\mathbf{X}$ & $\mathbf{X}$ & \\
\hline Total & $\mathbf{X}$ & $\mathbf{X}$ & $\mathbf{X}$ & \\
\hline
\end{tabular}

Table 2. EFAS Matrix for Pepper Auction Market in Sleman Regency Sleman Regency

\begin{tabular}{lcccc}
\hline $\begin{array}{c}\text { Internal Strategy } \\
\text { Factor }\end{array}$ & Weight & Rating & $\begin{array}{c}\text { Weight } \mathbf{X} \\
\text { Rating }\end{array}$ & Note \\
\hline Opportunity & $\mathbf{X}$ & $\mathbf{X}$ & $\mathbf{X}$ \\
Total & $\mathbf{X}$ & $\mathbf{X}$ & $\mathbf{X}$ \\
Weakness & $\mathbf{X}$ & $\mathbf{X}$ & $\mathbf{X}$ \\
Total & $\mathbf{X}$ & $\mathbf{X}$ & $\mathbf{X}$ \\
\hline Total & $\mathbf{X}$ & $\mathbf{X}$ & $\mathbf{X}$ \\
\hline
\end{tabular}


The internal and external factors then arranged in IFAS and EFAS matrix. After that, the Auction Market positioned in the Pearce-Robinsan diagram. Figure 1 showed that the determination of the coordinate point $(\mathrm{X}, \mathrm{Y})$ on the diagram was done using a formula (the total of strength score- the total of weakness score and the total of opportunities score- the total of threat score). The decision chosen was taken according to the company situation (Pearce and Robinson, 2008).

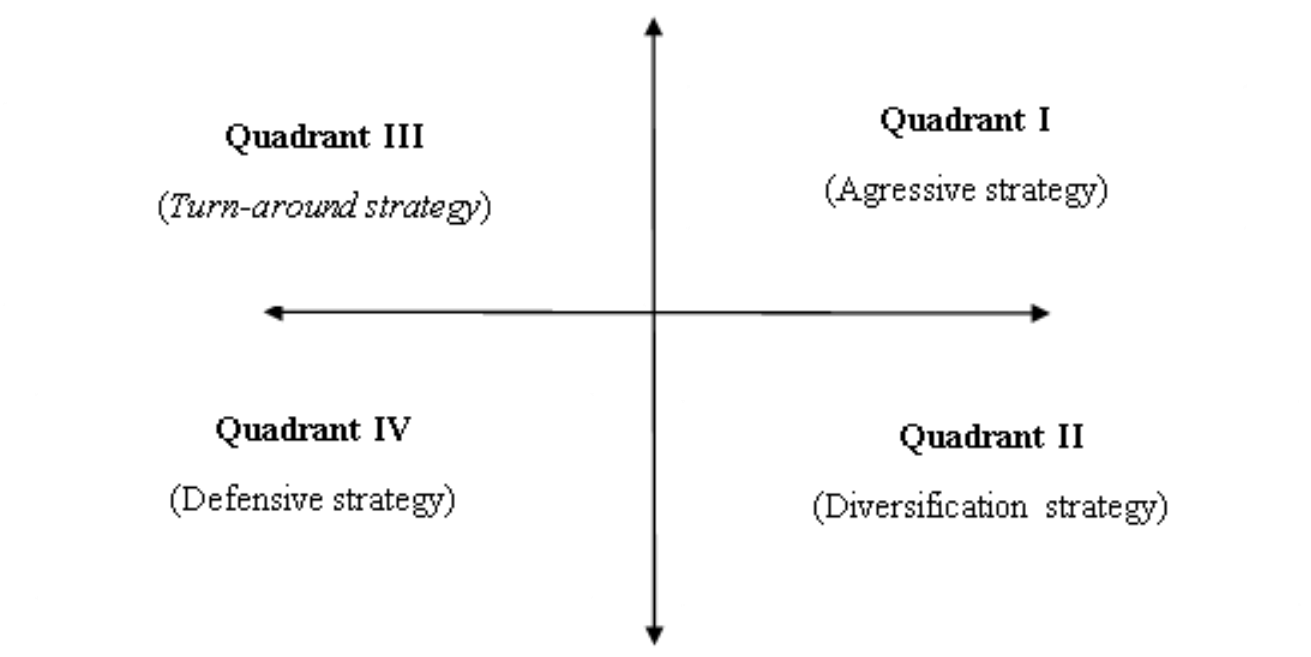

Figure 1. SWOT Analysis Quadrant

The SWOT matrix consisted of four alternative strategies, they are SO strategy, ST strategy, WO strategy, and WT strategy. Each strategy was defined differently as shown in Table 3.

Table 3. SWOT Analysis

\begin{tabular}{ccc}
\hline $\begin{array}{c}\text { Internal } \\
\text { Factors } \\
\text { External } \\
\text { Factors }\end{array}$ & Strengths (S) & Weaknesses (W) \\
\hline Opportunities $(\mathrm{O})$ & $\begin{array}{c}\text { Using strength to utilize } \\
\text { the opportunies. }\end{array}$ & $\begin{array}{c}\text { Removing the weakness to } \\
\text { utilize the opportunities. }\end{array}$ \\
\hline Threats $(\mathrm{T})$ & $\begin{array}{c}\text { ST Strategy } \\
\text { Using the strength to } \\
\text { manage the threat. }\end{array}$ & $\begin{array}{c}\text { Wemoving the weakness to } \\
\text { manage the threat. }\end{array}$ \\
\hline
\end{tabular}

\section{RESULT AND DISCUSSION}

\section{Sleman Pepper Auction Market General Profile}

The Sleman Pepper Auction Market was initiated by the Puncak Merapi Horticultural Farmer Group and officially operated on October 17th, 2017. The market located on the Palagan Tentara Pelajar Street, No. Km, Rw. 15, Glondong, Purwobinangun, Pakem District, Sleman Regency. This market was used to set an appropriate price and build a good payment system for the farmer by adopting an 
innovation strategy introduced by an auction market in Panjatan District, Kulon Progo Regency.

The Sleman Agricultural Departement and Indonesia Bank were facilitating the auction process in Sleman Auction Market. They were conducting a specific training for the auction management parties related to the pepper cultivation and providing some wards, scales, and three-wheeled vehicles for the market. At the end of 2019, this market started to use the "Panenin" application for recording the market administration.

The auction market participant was slowly increasing. The transparent system and good payment accountability were the main reason for the high farmer's enthusiasm in joining this market. Some assembly points also formed by the farmer to make the system run easier. In 2020 , there were 13 points of assembly point under the Puncak Merapi Horticultural Farmer Group and two assembly points outside this group. Those 13 assembly points were central assembly point (Bunder, Glondong, Purwobingun, Pakem), Turi, Tempel, Seyegan 1, Seyegan 2, Kebon Agung Sleman, Karangasem, Sariharjo (Ngaglik), Hargobinangun, Cawan (Ngemplak), Berbah, Kalasan, and Ngemplak. While the other two assembly points were Pondok 1 and Pondok 2.

The assembly point was functioned as a point for conducting some activities: weighing, recording, sortation, and grading, coordination involving the central management to determine the amount, quality, and type of pepper distributes in the market, pepper pick-up point, and assembly point to pay the pepper commodity. The sortation and grading process is done by using the standard operational procedure (SOP) set by the management parties. The sorting and grading must be done according to the quality and pepper type. After the sortation process, the auction management parties would announce the information related to the pepper quantity and quality to the central management parties. Then the auction management parties would deliver the pepper to the auction central management and waiting for the trader who won the auction session at that time. The central management would give the money from the auction process to the auction management parties. The money would be transferred to the farmers after the auction session. Despite, the farmer didn't sell the pepper directly to the central auction market, the farmer would accept the same amount of money as the amount of money accepted by the auction management.

The auction system used in Sleman was indirect. The trader didn't have to attend the auction market, they could be connected to the management parties by using their mobile phone. Some areas in Magelang and Klaten also do the same system. The standard operational procedure use on the auction system were:

1. The auction market management parties (marketing department) must be announced the amount of pepper, its quality, and its pepper type to the auction participant through a short message (WhatsApp/short message service/telephone).

2. The auction participant offered the prices they want to the management parties through a short message (WhatsApp/short message service/telephone). They only have one chance to offered a certain price and must be offered before 08.00 p.m. 
3. The management parties would summarize all prices offered and choose the highest price as the winner.

4. The management parties would announce the three highest prices offered by the auction participant in an announcement board provided by the auction market.

5. The auction participant who was winning the auction session would pay through a cash method or transferred it to the management parties. The payment must be done in three days after the transaction. The amount of money the must be paid was the pepper prices with an addition of IDR 500/ kg. The additional charge was used as the auction market's savings.

6. The trader could pick the pepper from the farmer or using a cargo to send the pepper.

7. If the winner did not want to buy all the pepper provided by the market, other traders could buy the number of pepper left using the price set by the winner and an additional charge of IDR $500 / \mathrm{kg}$.

\section{The Strategy Used to Develop Sleman Pepper Auction Market}

The internal and external condition was an important factor in arranging a strategy to develop the Sleman Pepper Auction Market. The internal factors analysis showed that the strength factors were higher than the weakness factors with the total of the difference of 0.073. The specific explanation of the strength and weakness factor is shown in Table 4.

Table 4. Sleman Pepper Auction Market IFAS Matrix

\begin{tabular}{|c|c|c|c|c|}
\hline & Internal Factors & Weight & Rating & Score \\
\hline \multicolumn{5}{|c|}{ Strength: } \\
\hline 1 & Strategic location & 0.115 & 4.000 & 0.461 \\
\hline 2 & $\begin{array}{l}\text { Providing a sortation and grading process } \\
\text { to assure the product quality matched the } \\
\text { price set }\end{array}$ & 0.152 & 4.000 & 0.608 \\
\hline 3 & Easy dealing process & 0.127 & 3.654 & 0.465 \\
\hline 4 & Fast dealing process & 0.085 & 3.615 & 0.307 \\
\hline 5 & Friendly services & 0.109 & 3.846 & 0.420 \\
\hline 6 & Good product quality & 0.130 & 3.846 & 0.500 \\
\hline 7 & $\begin{array}{l}\text { Providing product based on consumer's } \\
\text { need }\end{array}$ & 0.061 & 3.923 & 0.239 \\
\hline 8 & Providing product transparency's price & 0.109 & 3.962 & 0.432 \\
\hline 9 & Wide range of pepper distribution & 0.055 & 3.923 & 0.215 \\
\hline 10 & $\begin{array}{l}\text { Dealing process recorded using digital } \\
\text { technology }\end{array}$ & 0.058 & 3.692 & 0.214 \\
\hline \multicolumn{2}{|r|}{ Total } & 1.000 & - & 3.861 \\
\hline \multicolumn{5}{|c|}{ Weakness } \\
\hline 1 & Did not provide delivery service. & 0.127 & 3.692 & 0.469 \\
\hline
\end{tabular}


2 Some farmers didn't give the their pepper commodity to the auction management parties on time agreed by both parties which tended to cause a loss on the auction market

3 Some auction participants didn't pay the pepper based on time agreed with management parties

4 There was no written agreement used between the auction participant and management parties

5 Some assemby points didn't obey the rules set by market

6 Sone farmers didn't obey the cultivatio schedule set by the Sleman Agricultural Auction Market

\begin{tabular}{cccc}
\hline Total & $\mathbf{1 . 0 0 0}$ & - & $\mathbf{3 . 7 8 8}$ \\
\hline Strength Score-Weakness Score & & & 0.73 \\
\hline
\end{tabular}

Source : Primary Data Analysis, 2020

The main strength of the Sleman Auction Market was its sortation and grading system. This system played a major role in maintaining the product quality in the auction market. The most traders stated that the quality of pepper provided by the Sleman Auction Market was better than the pepper supplied by the wholesaler. The wholesaler tended to sort the pepper without separating the pepper grade or class. Therefore, the trader must do the grading system to classify the product quality. This process could meet the trader's need in maintaining product quality (the sixth indicator).

The next strength indicator was "easy dealing process". The payment system was relatively easy and simple which was done through transfer or cash payment method in three days after the auction winner announced. The dealing process also finished in less than 8 hours (the fourth indicator). The market location also could be easily accessed by transportation (pick up or truck) and tracked using Google Maps.

The transparency was the main strength of this auction market. The winner of each auction session would be announced on an announcement board provided by the market. The announcement would be shown to the farmers for 15-30 minutes after the winner of the auction announced. If the farmers couldn't see that announcement, they couldn't join that auction session. Hospitality from the management parties also majorly contributed to the bounding between the trader and the management parties.

Some indicators was showing a low score on the IFAS matrix. The indicator of "providing product based on the consumer's need" was having a low score because the market couldn't meet all trader's needs. The majority of traders was obtained product information from the management parties through a short message such as Whatsapp, short message service, or telephone. But on some traders stated they didn't get the information on the famine season due to the low pepper stock (only $1 / 2$ 
-1 ton/day). The normal amount of pepper on the usual season was around 7 tons/day. During the famine season, the management parties also send the product information to some traders who actively participated in the auction session. The next indicator "wide range of pepper distribution" and "dealing process recorded by the digital technology" were also having a low score. The digital recording was done using a "Panenin" application which supported by Bank Indonesia. This application was contained information about product quantity and product that only could be accessed by the market management parties.

The Sleman Auction Pepper Market weaknesses consisted of some indicators. The main weakness was the rules didn't completely obeyed by all assembly points. In 2020, there were 13 assembly points created around the Sleman Regency. The assembly functioned as a location for the farmer to gather their pepper commodity before it send to the auction market. The initial purpose of this assembly point was to make the auction system run easier among the farmer and trader. Unfortunately, the assembly point couldn't implement the SOP properly, especially in the coordination aspect and the sortation process. The coordination consisted of information about the quantity, quality, and type of pepper cultivated by the farmer. The sortation process also rarely done based on the SOP set by the market which caused low-quality pepper also traded during the auction session.

No written agreement/contract between the auction participant and auction management parties majorly affected the SWOT analysis score. This weakness providing a high chance for fraud practice among the traders. No written agreement/contract couldn't be processed based on the law appropriately. Once, a trader didn't pay the farmer's pepper completely based on the basic agreement noted on the SOP. The management parties were tried to solve that problem by contacting the trader and finding his home. The management parties finally couldn't obtain the rest of the money for paying the pepper. The trader then got blocked to participate in the next auction session. A written agreement/contract was already suggested by the management parties, but most traders were refused this suggestion. They think that a written contract is too complex and considered taboo during the transaction because of the high burden on the trader and the farmer side. Consequently the transaction was done just based on trust foundation.

Farmer's disobedience in implementing their cultivation plan also categorized as a weakness. The Sleman Health Department was arranging a cultivation plan to assure the pepper commodity still could be accessed by the community during the famine season. Most of the farmers didn't obey the rule and still cultivating based on their plan. Some farmers also couldn't send their pepper commodities according to the time agreed with the management parties. Farmers who were couldn't send their pepper on a certain auction session wouldn't involve in that auction session. Their pepper would be joined in the next session of the auction. The pepper quality usually getting lower on the next auction session which would affect the price offered by the trader.

The delivery process didn't majorly affected the auction market system. Farmers usually using their transportation or rent some transportation devices to deliver their pepper to some traders. The late payment is also being a weakness in the auction market. 
The next factor analyzed on the SWOT were the opportunities and threats. In this study, the difference between those factors was 0.211 or in other words the opportunities were stronger than the threats. Table 5 is shown the factors on the opportunities and threats' side.

Table 5. Sleman Pepper Auction Market EFAS Matrix

\begin{tabular}{lllll}
\hline \multicolumn{2}{c}{ External Factors } & Weight & Rating & Score \\
\hline Opportunities: & & & & \\
1. The availability of support from the & 0.278 & 3.920 & 1.090 \\
government & & 0.389 & 4.000 & 1.556 \\
2. The increasing pepper demand & 0.333 & 3.690 & 1.229 \\
3. High pepper production in Sleman & & &
\end{tabular}

\begin{tabular}{|c|c|c|c|}
\hline Total & 1.000 & & 3.875 \\
\hline \multicolumn{4}{|l|}{ Threats: } \\
\hline \multirow{2}{*}{$\begin{array}{l}\text { 1. The whosaler who operated arround the } \\
\text { auction market }\end{array}$} & 0.200 & 2.115 & 0.423 \\
\hline & 0.244 & 4.007 & 0.977 \\
\hline \multicolumn{4}{|l|}{ 2. Import policies set by the government } \\
\hline \multicolumn{4}{|l|}{ 3. The number of farmer participating on the } \\
\hline 4. Pest and pepper diseases & 0.178 & 4.077 & 0.726 \\
\hline \multicolumn{4}{|l|}{ 5. The climate change } \\
\hline Total & 1.000 & & 3.664 \\
\hline \multicolumn{3}{|l|}{ Opportunites Score - Threat Score } & 0.211 \\
\hline
\end{tabular}

Source : Primary Data Analysis, 2020

According to Table 3, the opportunities factor consisted of three indicators. The main indicator was the high market pepper demand in Indonesia. The high demand depended on Indonesia high population, culinary business trend, and Indonesian preference in spicy food. The next indicator was the high pepper production. Sleman Regency is the main area that produced pepper commodities in Jabodetabek area and placed on the 15th rank on the highest area who produce pepper in Indonesia. Therefore, this auction market was a potential marketing line in distributing the pepper commodity. Some government parties like Sleman Agricultural Departement, Indonesia Bank, Minister of Agriculture, and Minister of Information and Communication also supported the auction market in Sleman Regency. They were providing specific management trainings and routine monitoring on the auction market system. They were also creating some wards in the market to make the auction system run easier.

The threat factors consisted of five main indicators. The main threat was the import policies set by the government. These policies would increase the stock of pepper commodities and decreasing the local prices. The policies also increased the competitive tension between the local pepper and import pepper commodity. The pest, diseases (caterpillars, lice, yellow curly diseases, and rotten pepper), and random climate change were attacking the pepper during the cultivation period was the next threat faced by the farmer. These conditions decrease the quality and quantity of pepper cultivated. The farmer usually deals with this condition by doing 
the sortation and grading process. The Sleman Agricultural Department also providing an extention session to the farmer in dealing with these threats.

The indicator of "the number of farmers participating in the auction session slowly decrease" was not categorized as a serious threat faced by the auction market. The number of the trader who was participated in the auction session was slowly increasing each year. This indicator could majorly affect the auction market system only if the number of trader keep decreasing. The management parties tried to prevent this by actively maintaining the trust bonding with the traders. The last threat was the wholesaler who operated around the market. The wholesaler was highly threatened the auction market system when the market initially operated. Today, the wholesaler couldn't threaten the auction market system, because they offered lower prices than prices offered by the traders on the auction session.

Table 4 and Table 5 showed the coordinates of X and $Y$ on the SWOT diagram. The $\mathrm{X}$ coordinate obtained by finding the differences between the strength score and the weakness score on the IFAS matrix. The value of $\mathrm{X}$ was positive, so it was positioned on the Strenght (S) axis with the value of 0.073. While the Y coordinate obtained by finding the differences between the opportunities score and the threat score on the EFAS matrix. The value of $Y$ was positive, so it was positioned on the opportunity $(\mathrm{O})$ axis with the value of 0.211 . The $\mathrm{X}$ and $\mathrm{Y}$ coordinate could be written as $(\mathrm{X} ; \mathrm{Y})$ or $(0.073 ; 0.211)$ which described that Sleman Pepper Auction Market Sleman was located on the Quadrant I on the Pearce Robinson diagram.

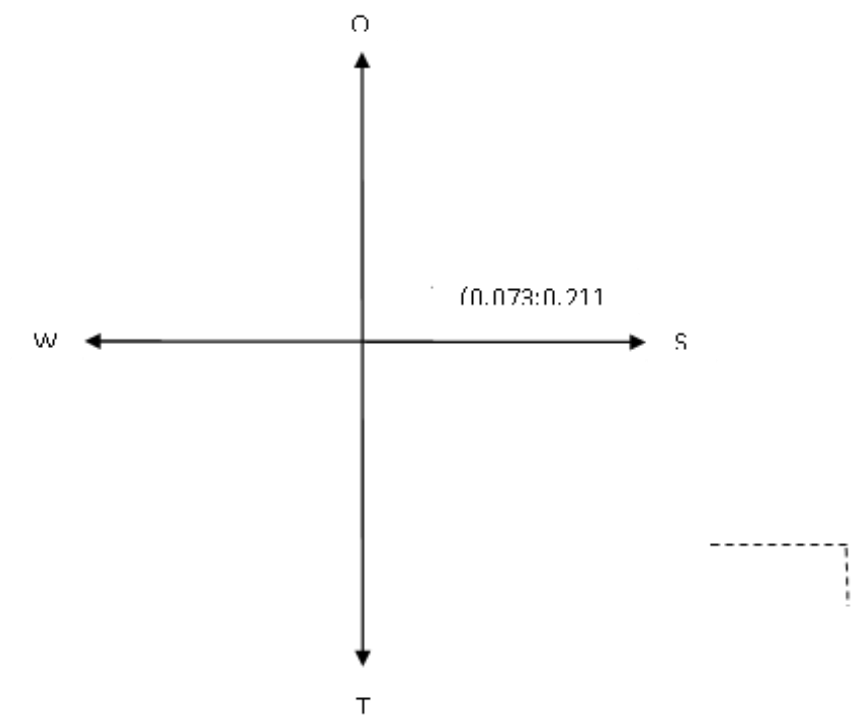

Figure 2. Sleman Pepper Auction Market Perason Robinson

The auction market positioned on the Quadrant I that showed the effective auction market development strategy through the qualitative approach was the aggressive strategy or SO (Strengths-Opportunity) strategy. The SO strategy used the internal strengths to utilize the opportunities in the external environment.

The first SO Strategy was conducted through improving the product quality. The sortation and grading process majorly contributed to the improvement of product quality. These processes must be done according to the SOP set by the market and strict supervision by the management parties. Some staff on the assembly points usually didn't use the instruction on SOP during the sortation and grading process which finally decrease the pepper quality. The management parties need to 
sustainably explaining the appropriate procedure for the sortation and grading process to those staff. Sustainable supervision also must be conducted to assure the staff working performance on the central auction market. These efforts done to guarantee the quality of pepper distributed on the auction market.

The second strategy was improving the production volume by the product intensification and conducting agricultural extention. The Sleman Agricultural Department suggested to conduct a sustainable cultivation extention to the farmer to assure the price stability and product availability. If the pepper stock increase too fast, the farmers could experiencing a massive loss. But a thorough cultivation plan would prevent this massive loss. A cultivation plan was also able to decrease the number of pepper imported by the government. The agricultural extention must be explained the cultivation techniques required to deal with the pest and irregular climate change. The extention would be better if delivered by the auction management parties who was also working as a farmer. The interpersonal communication between farmers would be more effective in delivering agricultural information. Through these strategies, we expect the farmer to cultivate the pepper based on the schedule planned by the agricultural department and able to provide the pepper commodity throughout the year.

Table 6. Sleman Pepper Auction Market Qualitative Approach SWOT Matrix

\section{Internal}

\section{Strength:}

1. Strategic location

2. Providing a sortation and grading process to assure the product quality matched the price set

3. Easy dealing process

4. Fast dealing process

5. Friendly services

6. Good product quality

7. Providing product based on consumer's need

8. Providing product transparency's price

9. Wide range of pepper distribution

10.Dealing process recorded using digital technology

\section{External}

\section{Opportunities:}

1. The availability of support from the government

2. The increasing pepper demand

3. High pepper production in Sleman

\section{S-O Strategy}

1. Improving product quality $\left(\mathrm{S}_{2,6,7}\right.$ dan $\mathrm{O}_{1,2,3}$

2. Improving pepper production volume $\left(\mathrm{S}_{7}\right.$ dan $\mathrm{O}_{1,2,3)}$

3. Improving services and build a good relationship with the assembly point and auction participants $\left(\mathbf{S}_{2,3,4,5,6,7,8,9}\right.$ dan $\mathrm{O}_{1)}$

4. Creating a online database contained of product and its price information $\left(\mathrm{S}_{6,7,8,9,10}\right.$ dan $\left.\mathrm{O}_{1,3}\right)$ 
The third SO-strategy was improving the services and communication between the assembly points and auction participants. The good communication between both parties able to provide valid and accurate information about the quality and quantity of pepper commodities in the assembly points and attracting more traders to buy the pepper commodity. This communication must be build based on trust and equality principles. The auction management parties must be able to give the same information to all trader involved in the auction session. Once, a management party was violating the SOP by obtaining more information to some traders. This action caused an unfair system in the auction market. Some auction participants also reported this case to Sleman Agricultural Department, but no further action was taken. Therefore, an open and transparent auction system urgently needs to be implemented. This effort could be done through an online auction system using a WhatsApp group that involving the management parties, auction participants, farmers, and the representative of the Sleman Agricultural Department with one chance to offered the price and limited time to offer those prices. The SOP also need to be revised by adding more detail explanation about the term and condition of the auction winner in buying all pepper commodity provided by farmers in an auction session. These steps expect to improve the trust between the traders and the auction management parties which would increase the number of traders participated in this auction system.

The fourth strategy was creating an auction open online database which contains information about the pepper product and its prices. This strategy was able to increase the number of farmers and traders to participate in the auction market. The "Panenin" application was a database that contains information about the product volume and product price that only accessed by the auction management parties. A new application or system that could be accessed by the farmer and trader is required to be built in improving the auction market dynamic. A website that could provide the product information and price, a platform for online auction, and a written agreement between the trader and farmer is another online database that could be developed to involve all parties on the auction market. A collaboration with the Minister of Information and Communication would help the development of this website.

\section{CONCLUSION}

The SWOT analysis showed that the most appropriate strategy in developing an auction market in Sleman Regency was the SO strategy. This strategy conducted by improving the product's quantity and quality, improving the quality of services, building a good relationship between the management parties, and arranging an online database that contains products and auction market information.

\section{RECOMMENDATION}

The auction market management parties and stakeholder is suggested to conduct a sustainable monitoring on the auction process, on the auction point or central auction market. Monitoring is playing an important role in preventing standard operational procedure violations (especially on the sortation and grading process). A routine meeting is also required to assure the auction process conducted based on the standard operational procedure. While to assure the transparency 
during the auction, the management parties suggested to collaborate with the Minister of Information and Communication to build an application or website to provide accurate auction information. Further research also needs to review a farmer's perspective in developing the auction market.

\section{REFERENCES}

Argade, A., \& Laha, A. (2018). E-commerce in oligopsonistic and relational markets - An empirical investigation of transaction costs in agricultural e- markets in India from farmers' perspective. Working Paper IIM Ahmedabad, 1-19.

Damona, R., Sarjana, I., \& Anggreni, I. (2013). Kajian Terhadap Implementasi Pasar Lelang Komoditi Agro pada Dinas Perindustrian dan Perdagangan Provinsi Bali. E-Journal Agribisnis Dan Agrowisata (Journal of Agribusiness and Agritourism), 2(4), 204-213.

Devi, P., Harsoyo, H., \& Subejo, S. (2015). Keefektifan Lembaga Pasar Lelang Cabai Merah Di Kecamatan Panjatan Kabupaten Kulon Progo. Agro Ekonomi, 26(2), 139. https://doi.org/10.22146/agroekonomi.17273

Fauziah, F. (2017). Respons petani lahan pasir pantai terhadap pemasaran sistem lelang cabai di Kecamatan Panjatan Kabupaten Kulon Progo, Yogyakarta. 3, 94-98. https://doi.org/10.13057/psnmbi/m030116

Gurel, E., \& Tat, M. (2017). SWOT Analysis: A Theoretical Review. The Journal of International Social Research, 10(51): 994-1006.

Kusumaningrum, F. Z., Juliman., \& Dalvi, M. (2015). Social Quality Masyarakat Lahan Pasir Pantai Pada Aspek Social Empowerment di Kecamatan Panjatan (Social Quality of Sand Land Community on Social Aspect of Empowerment in Panjatan Sub-district, Kulon Progo Regency. Agriekonomika, 4, 1-9.

Nugroho, A. D., Yoga Prasada, I. M., Kirana, S., Anggrasari, H., \& Nawang Sari, P. (2018). Rantai Nilai Cabai di Lahan Pasir Pantai Kabupaten Kulon Progo. Economics Development Analysis Journal, 7(4): 458-467. https://doi.org/10.15294/edaj.v7i4.25013.

Ommani, A. R. (2011). Strengths, weaknesses, opportunities and threats (SWOT) analysis for farming system businesses management: Case of wheat farmers of Shadervan District, Shoushtar Township, Iran. African Journal of Business Management, 5(22), 9448-9454.

Parining, N., \& Dewi, R. K. (2018). Analisis Risiko Pendapatan Cabai Merah Pada Lahan Sawah Dataran Tinggi Di Kabupaten Karangasem, Bali. SOCA: Jurnal Sosial Ekonomi Pertanian, 109. https://doi.org/10.24843/soca.2018.v12.101.p09

Pearce, J. A., \& Robinson, R. B. (2008). Manajemen Strategi Edisi 10. Jakarta: PT Gramedia. 
Perdana, A. S. (2016). Pemberdayaan Kelompok Tani Melalui Pasar Lelang Sebagai Solusi Mewujudkan Kedinamisan Kesejahteraan Petani. VIGOR: Jurnal Ilmu Pertanian Dan Subtropika, 1(1), 52-63.

Purwandani, K. M., Rahayu, W., \& Setyowati, N. (2016). Strategi Pengembangan Pasar Lelang Cabai Merah Lahan Pasir Pantai di Kawasan Pesisir Kecamatan Panjatan, Kabupaten Kulon Progo. Agrista, 4(3), 414-426.

Raya, A. B. (2014). A comparison of the function of leader-member exchange in two neighboring farmer groups in a sandy land area in Yogyakarta province, Indonesia. Asian Social Science, 10(12), 21-34. https://doi.org/10.5539/ass.v10n12p21

Rusdiyana, E. (2015). Manajemen Kelembagaan Pasar Lelang dalam Memfasilitasi Pemasaran Cabai Kelompok Tani Lahan Pasir Pantai di Kecamatan Panjatan Kabupaten Kulon Progo. Sungkai, 3(2), 49-64. 